\title{
Skin-core adhesion in high performance sandwich structures*
}

\author{
Yi-ou SHEN ${ }^{\dagger 1}$, Wesley CANTWELL ${ }^{2}$, Yan LI $^{\dagger+1}$ \\ $\left({ }^{1}\right.$ School of Aerospace Engineering and Applied Mechanics, Tongji University, Shanghai 200092, China) \\ ('Department of Aerospace Engineering, Khalifa University of Science, Technology and Research (KUSTAR), Abu Dhabi, UAE) \\ †E-mail: syoeva@tongji.edu.cn; liyan@tongji.edu.cn \\ Received Aug. 27, 2013; Revision accepted Dec. 5, 2013; Crosschecked Dec. 20, 2013
}

\begin{abstract}
The aim of this study is to characterize the interfacial fracture toughness of a micro-lattice core based sandwich structure from quasi-static to dynamic rates of loading. The modified three-point bend (MTPB) sandwich beam was used to characterize the interfacial properties of these sandwich structures. Dynamic tests were undertaken of up to $3 \mathrm{~m} / \mathrm{s}$ using a purpose-built instrumented drop-weight impact tower. Data reduction was accomplished through the use of a compliance calibration procedure similar to that used for characterizing the delamination resistance of composites. The flexural properties of sandwich beams were investigated through three-point bend tests at a cross-head displacement rate of up to $3 \mathrm{~m} / \mathrm{s}$. A detailed examination of the impact region highlighted the failure processes in these systems and this was related to the data from the quasi-static flexural tests. The globalized deformation and energy absorption during progressive were also discussed.
\end{abstract}

Key words: Sandwich structure, Interfacial fracture toughness, Flexural property

doi:10.1631/jzus.A1300283 Document code: A CLC number: TB3

\section{Introduction}

There is a growing interest in the potential offered by metallic foams, such as sandwich structures that are based on aluminium and steel for use in a range of energy absorbing structures. Many of the next generation of aerospace materials will employ advanced manufacturing techniques for cellular materials with a high strength to weight ratio and improved impact resistance under critical loading cases, such as foreign object impact from birds, tire rubber, and runway debris. However, one of the principal limitations of these systems is the irregularity of the cell structure within the metal foam, an effect that can result in overly conservative design criteria. Recently, workers have highlighted a number of core architectures that offer superior strength and stiffness to

\footnotetext{
Corresponding author

* Project supported by the Engineering and Physical Sciences Research Council (EPSRC) (No. EPSRC EP/C009525/1) of China, and the China Postdoctoral Science Foundation (No. 2011M500625) (C) Zhejiang University and Springer-Verlag Berlin Heidelberg 2014
}

weight ratios to those offered by foams (Deshpande and Fleck, 2001; Deshpande et al., 2001a; 2001b; Chiras et al., 2002; Wang et al., 2003; Zok et al., 2003). The complex architecture of the unit-cells in these cores can now be produced using the selective laser melting (SLM) process. SLM is a layered manufacturing technique by which parts of high complexity can be built from metal powder in relatively short timescales (Brooks et al., 2005).

Lattice structures can be used as core materials in efficient aerospace sandwich construction. The structure weight can be saved by up to $50 \%$ and the use of additive manufacturing techniques would also reduce material wastage in manufacturing. Currently $90 \%$ of the material that is used to make an airframe is wasted, due to the machining (subtractive) techniques used. Hence, this exploitation addresses lighter structures and a reduced material wastage, with both environmental and cost benefits.

Defects in sandwich structures are often inevitable and can originate both from manufacturing and use. In use, damage from loads, e.g., impact, 
might result in the formation of a debond or crack. With debonds present, the structure might fail at loads significantly lower than those for the undamaged sandwich structure. In recent years, a number of researchers have developed fracture mechanics test geometries to characterize the fracture properties of the skin-core interface in composite sandwich structures (Zenkert, 1989; Cantwell and Davies, 1994; Cantwell et al., 1996). Zenkert (1989) employed a cracked Mode II-type specimen to investigate failure in sandwich structures based on a foam core. A number of new specimen geometries were developed to study skin-core decohesion in balsa and foam sandwich structures (Cantwell and Davies, 1994; Cantwell et al., 1996). Scudamore (1999) showed that exposure to a sea-water environment can have a deleterious effect on the fracture properties in sandwich structures.

The studies of lattice structures as core materials in sandwich construction have shown that they offer a high degree of homogeneity of mechanical properties over traditional stiffened structures. Work has been carried out in studying the mechanical properties, crush behaviours, as well as impact properties of the selective laser melting (SLM) SS316L stainless steel and Ti64 titanium alloy micro-lattice (Santorinaios et al., 2006; McKown et al., 2007; 2008; Mines, 2008; Mines et al., 2008; Shen et al., 2010; 2013). This study aims to discuss the interfacial fracture properties of a stainless steel lattice core-based sandwich structure in order to improve the damage tolerance of sandwich structures and increase the toughness between skin and core.

\section{Experimental}

\subsection{Materials}

Stainless steel 316L lattice structures were manufactured using the SLM technique (Brooks et al., 2005). The technique was used to manufacture beam samples with dimensions of $150 \mathrm{~mm} \times 25 \mathrm{~mm} \times 25 \mathrm{~mm}$ for the modified three-point bend (MTPB) test, and $100 \mathrm{~mm} \times 20 \mathrm{~mm} \times 20 \mathrm{~mm}$ for the flexural test. The hierarchy of the lattice structure was formed from the repetition of a single unit-cell based on a $\pm 45^{\circ}$ boay-centered cubic (BCC) geometries, which contains a node located at the centre of a cube from which all the unit-cell struts radiate out to the corner vertex locations of the cube. The struts have an average cross-sectional diameter of $0.2 \mathrm{~mm}$, determined from scanning electron microscope (SEM) image analysis. The density of the lattice structure is $8.0 \mathrm{~g} / \mathrm{cm}^{3}$.

The metallic cores were incorporated into sandwich beams using a relatively simple hotstamping manufacturing technique (Reyes and Cantwell, 2000). The skins of the sandwich structures were based on 12 layers woven carbon fibre reinforced plastic (CFRP) for the MTPB test, giving a nominal thickness of $3 \mathrm{~mm}$ in order to provide enough flexural rigidity during the test to make sure that the top skin will not be fractured before debonding; and the skins of samples for flexural test were based on four layers of woven CFRP, giving a nominal thickness of $1 \mathrm{~mm}$. The pressure applied during moulding was maintained below the yield stress of the core structure, and the temperature was maintained at $125^{\circ} \mathrm{C}$ for $2 \mathrm{~h}$. After the mould had cooled, the sample was removed in preparation for testing.

\subsection{Impact tests}

Impact tests were conducted on the instrumented drop-weight impact tower as shown in Fig. 1. An instrumented carriage was released from the required height in order to generate increased levels of crush within the samples. The variation of load with time during the impact tests was measured using a piezoelectric load-cell positioned directly underneath the base on the test rig. The velocity of the impactor during the impact event was measured using a high speed camera. The velocity versus time traces from the velocimeter were recorded by a dedicated computer and subsequently integrated to yield displacement versus time traces. Dynamic MTPB and flexural tests were also carried out on the drop-weight tower. Details of the impact tests on the sandwich beams are given in Table 1.

The MTPB was developed to characterize the interfacial fracture toughness of the sandwich structures (Cantwell et al., 1997). The Mode I interlaminar fracture toughness $G_{\mathrm{IC}}$ was determined using an experimental compliance approach,

$$
C=K a^{n},
$$




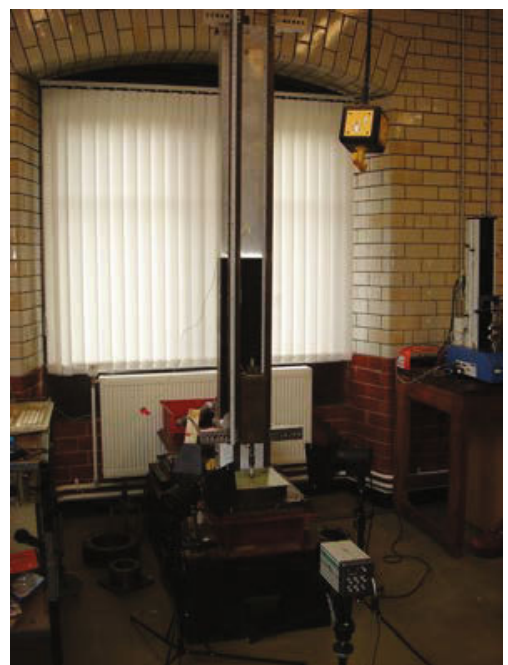

Fig. 1 The drop-weight rig used for characterising the dynamic properties of samples

Table 1 Details of the impact tests applied on the sandwich beams

\begin{tabular}{|c|c|c|c|}
\hline $\begin{array}{l}\text { Test } \\
\text { method }\end{array}$ & $\begin{array}{l}\text { Support/Span, } \\
L(\mathrm{~mm})\end{array}$ & Impactor & $\begin{array}{l}\text { Loading ve- } \\
\text { locity }(\mathrm{m} / \mathrm{s})\end{array}$ \\
\hline МТРВ & $\begin{array}{l}\text { Two } 10 \mathrm{~mm} \text { diameter } \\
\text { cylinders, } L=140\end{array}$ & $\begin{array}{l}10 \text { mm diameter } \\
\text { cylindrical bar }\end{array}$ & $\leq 3$ \\
\hline Flexural & $\begin{array}{l}\text { Two } 10 \mathrm{~mm} \text { diameter } \\
\text { cylinders, } L=80\end{array}$ & $\begin{array}{l}10 \mathrm{~mm} \text { diameter } \\
\text { cylindrical bar }\end{array}$ & $\leq 4$ \\
\hline
\end{tabular}

where $n$ is the slope of this plot, then

$$
G_{\mathrm{IC}}=\frac{n P \delta}{2 b a},
$$

where $P$ is the load, $\delta$ is the displacement, $b$ is the specimen width, and $a$ is the crack length.

In the case of the MTPB sample, a $15 \mathrm{~m}$ wide folded aluminum foil was placed at one end of the beam between the upper composite skin and the BCC lattice and aluminum foam core to act as a pre-crack. The lower skin and the core at this end of the beam were removed, leaving a section of the upper face-sheet material protruding from the remaining sandwich specimen (Fig. 2). A loading rate between $1.7 \times 10^{-6} \mathrm{~m} / \mathrm{s}$ and $3 \mathrm{~m} / \mathrm{s}$ was employed. The crack length was measured by an eye on the specimen edge, using a travelling microscope or high speed camera. A thin layer of white ink was painted on the specimen edge, with dark marks made every $5 \mathrm{~mm}$.

The flexural response of the sandwich beams based on stainless steel 316L BCC lattice cores was investigated through a series of three-point bend tests at crosshead displacement rates from $4.2 \times 10^{-6} \mathrm{~m} / \mathrm{s}$ to $4 \mathrm{~m} / \mathrm{s}$.

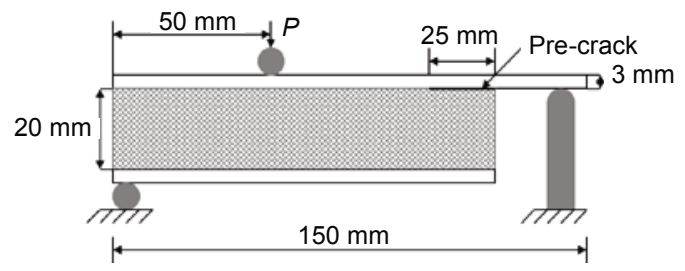

Fig. 2 Schematic of the modified three-point bend (MTPB) sandwich specimen

\section{Results and discussion}

\subsection{Sandwich beam core-skin interface}

Prior to conducting the MTPB tests, the nature of the sandwich core-skin interface was investigated. Fig. 3 shows a side view of a three-point bend sandwich beam, the strands penetrate to a depth of approximately two plies (i.e., half way through the thickness of the skin). This is consistent along the length of the beam, suggesting that the manufacturing process can be carefully controlled by uniformly applying the correct pressure to achieve a desired depth of penetration into the skin. This results in a smooth surface finish, with no surface irregularities caused by stainless steel strands penetrating into the skin.

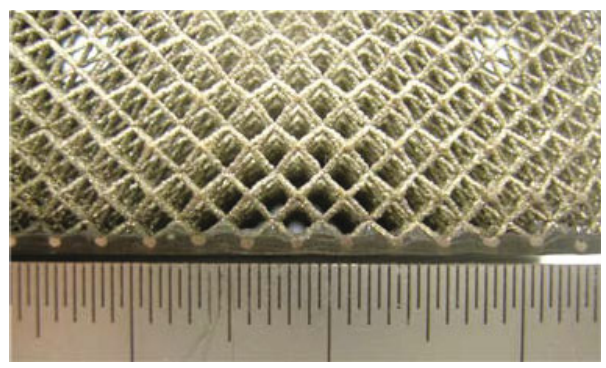

Fig. 3 Core-skin interface showing the penetration of the lattice to a depth of approximately two composite plies

\subsection{Interfacial properties of sandwich structures}

A typical load versus crosshead-displacement record obtained from a quasi-static MTPB test is shown in Fig. 4. Crack propagation was found unstable as highlighted in the figure. It can be seen from Fig. 4a that strands attached to the upper skin started 
to stretch in the beginning, and a shear band occurred at the fracture initiation with applied load increase, then crack propagation extended from the pre-crack resulting in a slight drop in load; afterwards, load steady increased causing skin bending and localized core crushing. An SEM photograph showed strand failures similar to those observed in the tensile tests. The initial fracture toughness $G_{\mathrm{IC}}$ was used to characterize the delamination resistance of the lattice sandwich structure since crack propagation in the MTPB test involved tearing of the core but no strand extraction out of the skin.

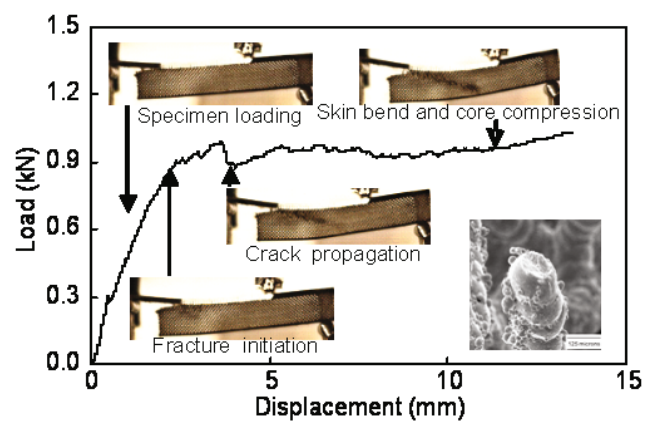

(a)

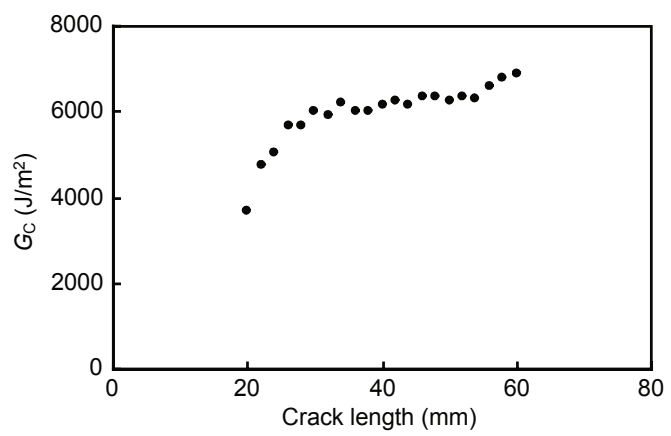

(b)

Fig. 4 A typical load vs. displacement curve (a) and a typical $G_{I C}$ vs. crack length plots of MTPB test on a lattice sandwich beam at a loading rate of $4.2 \times 10^{-6} \mathrm{~m} / \mathrm{s}(\mathrm{b})$

A series of drop-weight impact tests were carried out on the 316L lattice-based MTPB samples in order to characterize the dynamic fracture properties of the skin-core interface. Since it was not possible to characterize the skin-core delamination resistance during a test due to crack propagation through the core, the initial fracture toughness $G_{\mathrm{C}}$ was used to characterize the delamination resistance of the lattice sandwich structures. Relatively high $G_{\mathrm{IC}}$ values were obtained, which were approximately $5500 \mathrm{~J} / \mathrm{m}^{2}$ at quasi-static rate, and $6500 \mathrm{~J} / \mathrm{m}^{2}$ under a low velocity impact loading of $3 \mathrm{~m} / \mathrm{s}$. Fig. 5 suggests that $G_{\text {IC }}$ increased by approximately $15 \%$ from $8.4 \times 10^{-6} \mathrm{~m} / \mathrm{s}$ to $3 \mathrm{~m} / \mathrm{s}$.

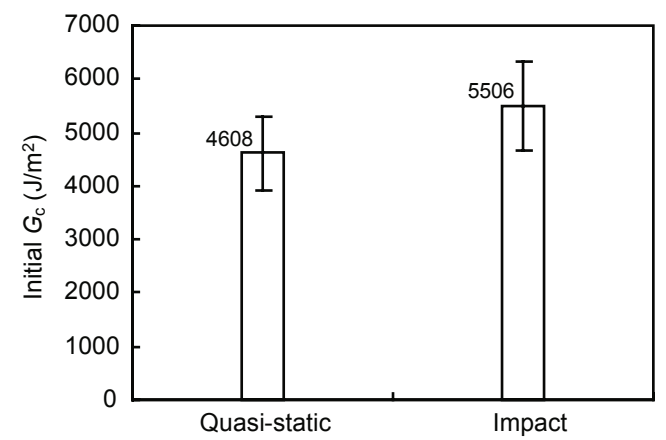

Fig. 5 Values of $G_{\mathrm{C}}$ at initiation at quasi-static rate $\left(8.4 \times 10^{-6} \mathrm{~m} / \mathrm{s}\right)$ and impact loading rate $(3 \mathrm{~m} / \mathrm{s})$

\subsection{Flexural properties of sandwich structures}

Typical quasi-static lattice sandwich beam load-displacement curves are shown in Fig. 6a with a peak load of approximately $1.1 \mathrm{kN}$ and an initial stiffness of $1.77 \mathrm{kN} / \mathrm{mm}$. No evidence of delamination was observed when the beams were subjected to quasi-static and impact loads under three-point bending (Fig. 6b).

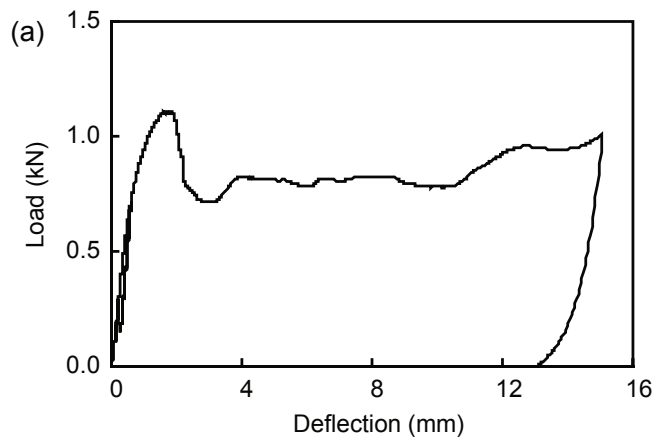

(b)

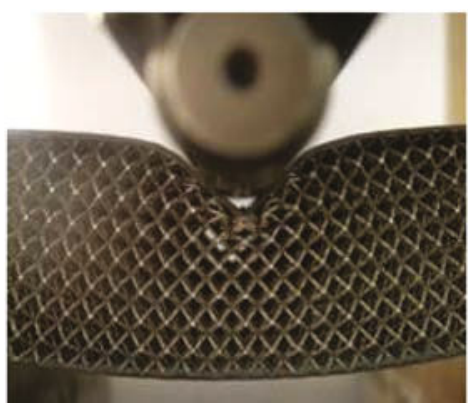

Fig. 6 Three-point bend test on a lattice sandwich beam (a) Loading rate of $4.2 \times 10^{-6} \mathrm{~m} / \mathrm{s}$; (b) Side view of sandwich beam subjected to three-point bend loading 
Previous work on sandwich beams based on a metal core has shown that such structures fail in a number of modes: face yielding, face wrinkling, core yielding, and indentation (Fig. 7) (Ashby et al., 2000). Similar failure modes were observed during this study, as shown in Fig. 7. Failure of the skin initiated at the initial peak load, which was followed by progressive crushing of the core. During indentation, localized crushing of the core occurred by plastic bending of the strands, which was similar to that observed in the compression tests. The indentation pressure on the foam core is only slightly higher than the uniaxial compressive strength. It can be seen in Fig. $7 \mathrm{c}$ that the loading crushes the lattice, bending the face sheet to accommodate the lattice core deformation. Two competing collapse mechanisms were identified in sandwich beams following three-point bending: Mode A and Mode B (Ashby et al., 2000). In collapse Mode A, the formation of plastic hinges happens at the loading point during the core shear. In collapse Mode B, the collapse mechanism is accompanied by the formation of plastic hinges at the mid-span and the support point. In this study, the lattice sandwich beam sheared in the collapse Mode B. Here, a cylinder indenter was used here and no mid-span plastic hinge was observed, only the existence of shearing at the outer supports was observed (Fig. 7d). This was caused by a transverse shear force in the core, and a plastic collapse by core shear can result.

The energy-absorbing capacity of the sandwich structures was investigated by determining the energy under the load-displacement traces. Fig. 8 shows the variation of the absorbed energy with the impact energy, where it is evident that over $80 \%$ of the incident energy of the impactor is absorbed in failure processes within the sandwich structure. It is believed that much of this energy is absorbed by plastically deforming the struts under the point of impact, although some will clearly be dissipated in damaging and fracturing the skins.

Drop-weight tests produced a linear response between the residual deflection after testing and impact energy, as shown in Fig. 9. The SEM photographs also show that the energy absorbed by the lattice core increased with deflection by cell collapsing, while the upper skin showed more damage.

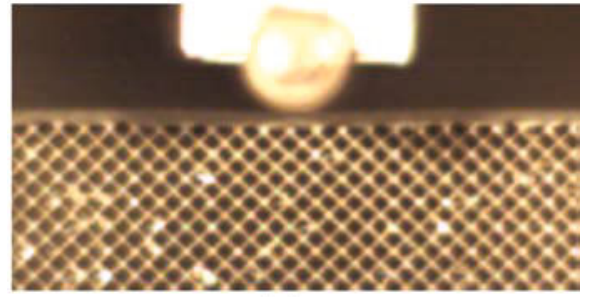

(a)

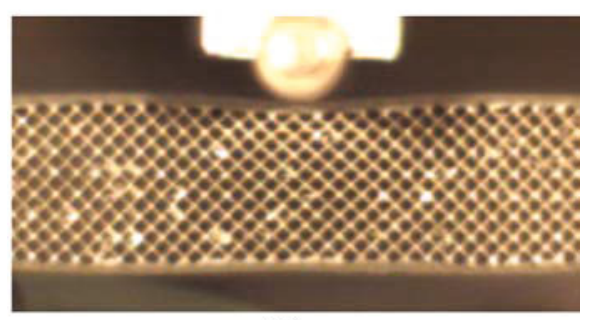

(b)

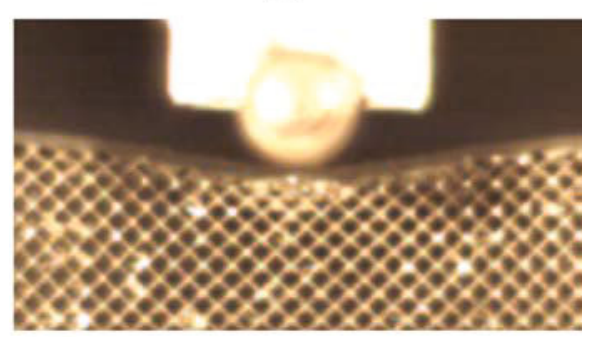

(c)

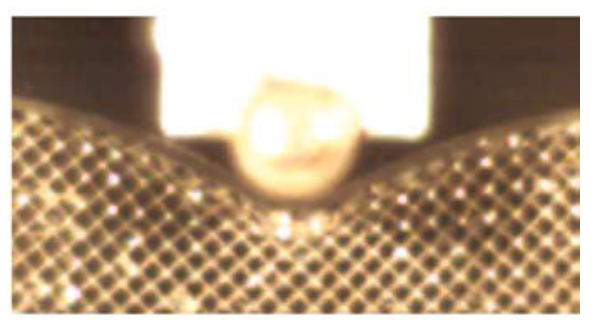

(d)

Fig. 7 Failure modes of sandwich beams based on 316L lattice core with a loading rate of $2 \mathrm{~m} / \mathrm{s}$

(a) Face yielding; (b) Face wrinkling; (c) Core yielding; (d) indentation

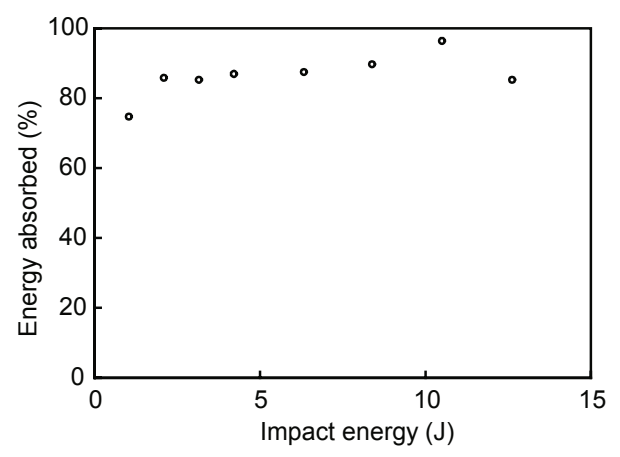

Fig. 8 Plots of the percentage of the total impact energy absorbed by the sandwich beams against impact energy 


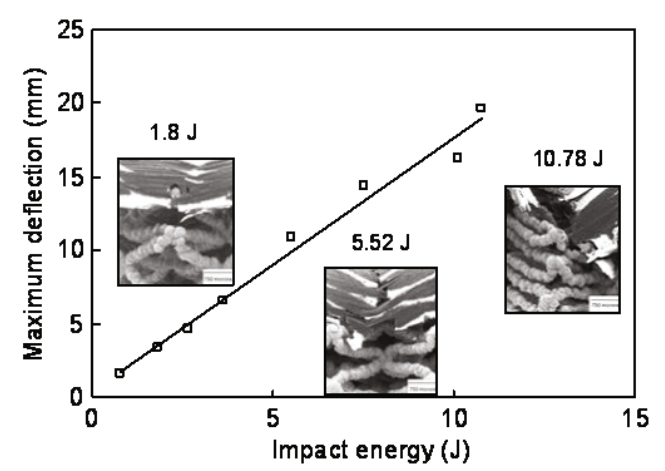

Fig. 9 Permanent deflection versus impact energy

\section{Conclusions}

Sandwich structures were manufactured using a simple process without the need for a core-skin adhesive. These samples showed excellent bonding at the interface, with no delamination being observed when being loaded statically and dynamically in three-point bending. An analysis of the composite sandwich beams showed that metal lattices can be used as cores with excellent delamination resistance. The skin-sore delamination resistance of a number of sandwich structures was investigated using a simple three-point bend fracture mechanics specimen. Tests showed that metal lattice structures offer an excellent skin-core delamination resistance with fracture energies approaching $5500 \mathrm{~J} / \mathrm{m}^{2}$. Tests at higher rates of strain also showed that it is possible to characterize the fracture properties of lightweight sandwich structures at loading rates up to impact loading conditions.

\section{References}

Ashby, M.F., Evans, A., Fleck, N.A., et al., 2000. Metal Foams: A Design Guide. Butterworth-Heinemann, Oxford.

Brooks, W.K., Todd, J., Sutcliffe, C.J., 2005. The production of open cellular lattice structures using selective laser melting. Sixth National Conference on Rapid Prototyping, Design, and Manufacturing, Lancaster University, UK.

Cantwell, W.J., Davies, P., 1994. A test technique for assessing core-skin adhesion in composite sandwich structures. Journal of Materials Science Letters, 13(3):203-205. [doi:10.1007/BF00278162]

Cantwell, W.J., Broster, G., Davies, P., 1996. The Influence of water immersion on skin-core debonding in GFRP-Balsa sandwich structures. Journal of Reinforced Plastic and Composites, 15:1161-1172.
Cantwell, W.J., Scudamore, R.J, Davies, P., et al., 1997. A study of skin-core adhesion in composite sandwich materials. Proceedings of 11th International Composite Materials, Woodhead, p.905-914.

Chiras, S., Mumm, D.R., Evans, A.G., et al., 2002. The structural performance of near-optimized truss core panels. International Journal of Solids and Structures, 39(15): 4093-4115. [doi:10.1016/S0020-7683(02)00241-X]

Deshpande, V.S., Fleck, N.A., 2001. Collapse of truss core sandwich beam in 3-point bending. International Journal of Solids and Structures, 38(36-37):6275-6305. [doi:10. 1016/S0020-7683(01)00103-2]

Deshpande, V.S., Ashby, M.F., Fleck, N.A., et al., 2001a. Effective properties of the octet-truss lattice material. Journal of the Mechanics and Physics of Solids, 49(8): 1747-1769. [doi:10.1016/S0022-5096(01)00010-2]

Deshpande, V.S., Ashby, M.F., Fleck, N.A., 2001b. Foam topology bending versus stretching dominated architectures. Acta Materialia, 49(6):1035-1040. [doi:10.1016/ S1359-6454(00)00379-7]

McKown, S., Cantwell, W.J., Brooks, W.K., et al., 2007. High-performance sandwich structures with hierarchical lattice cores. Proceedings of 28th International European SAMPE, Europe, p.396-401.

McKown, S., Shen, Y., Brooks, W.K., et al., 2008. The quasistatic and blast loading response of lattice structures. International Journal of Impact Engineering, 35(8): 795-810. [doi:10.1016/j.ijimpeng.2007.10.005]

Mines, R.A.W., 2008. On the characterisation of foam and micro-lattice materials used in sandwich construction. Strain, 44(1):71-83. [doi:10.1111/j.1475-1305.2008. 00399.x]

Mines, R.A.W., McKown, S., Tsopanos, S., et al., 2008. Local effects during indentation of fully supported sandwich panels with micro lattice cores. Applied Mechanics and Materials, 13-14:85-90. [doi:10.4028/www.scientific.net/ AMM.13-14.85]

Reyes, G., Cantwell, W.J., 2000. The mechanical properties of fiber-metal laminates based on glass fiber reinforced polypropylene. Composites Science and Technology, 60(7):1085-1094. [doi:10.1016/S0266-3538(00)00002-6]

Santorinaios, M., Brooks, W., Sutcliffe, C.J., et al., 2006. Crush behaviour of open cellular lattice structures manufactured using selective laser melting. WIT Transactions on the Built Environment, 85:481-490.

Scudamore, R., 1999. Interfacial Fracture in Sandwich Laminates. PhD Thesis, University of Liverpool.

Shen, Y., McKown, S., Tsopanos, S., et al., 2010. The mechanical properties of sandwich structures based on metal lattice architectures. Journal of Sandwich Structures and Materials, 12(2):159-180. [doi:10.1177/1099636209104 536]

Shen, Y., Cantwell, W.J., Mines, R., et al., 2013. Low-velocity impact performance of lattice structure core based sand- 
wich panels. Journal of Composite Materials, in press. [doi:10.1177/0021998313507616]

Wang, J., Evans, A.G., Dharmasena, K., et al., 2003. On the performance of truss panels with Kagome cores. International Journal of Solids and Structures, 40(25):69816988. [doi:10.1016/S0020-7683(03)00349-4]

Zenkert, D., 1989. Poly(vinyl chloride) sandwich core materials: Fracture behaviour under mode II loading and mixed-mode conditions. Materials Science and Engineering: A, 108:233-240. [doi:10.1016/0921-5093(89) 90425-5]

Zok, F.W., Rathbun, H.J., Wei, Z., et al., 2003. Design of metallic textile core sandwich panels. International Journal of Solids and Structures, 40(21):5707-5722. [doi:10.1016/ S0020-7683(03)00375-5]

\section{中文概要:}

\section{本文题目：高性能夹芯结构的面板与芯材的黏合性能}

Skin-core adhesion in high performance sandwich structures

研究目的 : 通过准静态到动态的加载, 研究以不锈钢点阵结构为芯材的夹芯结构的层间断裂㓞性。

创新要点: 制备的夹芯结构不需要黏合剂, 但是具有优异的面板-芯材界面性能; 证明改良后的三点弯 曲实验可用于研究夹芯结构在低速冲击下的界面性能。

研究方法 : 采用改良后的三点弯曲实验（见图 2) 测试夹芯结构的面板-芯材断裂㓞性; 采用低速冲击来 测试夹芯结构的抗分层性能（见图 5) 和吸收能量性能（见图 8)。

重要结论 : 1. 采用热压法制备的以碳纤维增强环氧树脂预浸料为面板, 不锈钢点阵结构为芯材的夹芯结 构不需要任何粘合剂; 2. 所得夹芯结构在受到准静态和动态三点弯曲加载时展现了优异的抗 面板-芯材界面分层性能, 断裂能达到 $5500 \mathrm{~J} / \mathrm{m}^{2}$; 3. 改良的三点弯曲实验可以用于测试低速 冲击条件下夹芯结构的断裂性能。 